\title{
The Political Economy of the Sustainable Development Goals (SDGs): Does Performance on the SDGs Affect Re-Election?
}

\author{
Christian Kroll ${ }^{1, *}$ (i) and Vera Zipperer ${ }^{2,3}$ \\ 1 SDG Index \& Dashboards, 10117 Berlin, Germany \\ 2 Faculty of Economics and Management, Technical University, 10623 Berlin, Germany; vzipperer@diw.de \\ 3 DIW Berlin, 10117 Berlin, Germany \\ * Correspondence: christian.kroll@bertelsmann-stiftung.de
}

Received: 27 May 2020; Accepted: 22 July 2020; Published: 10 August 2020

\begin{abstract}
While the economic voting hypothesis is a well-researched approach to explain behavior at the ballot box, a broader perspective of economic, social and environmental issues regarding a government's chances to get re-elected is still missing in the literature. In this context, this paper makes use for the first time of the Agenda 2030 with its 17 Sustainable Development Goals (SDGs) as the comprehensive policy framework that all $193 \mathrm{UN}$ member states have pledged to achieve. The objective of our study is therefore to examine the relationship between SDGs' progress and the likelihood of re-election. Our analysis of 124 countries regarding performance on the SDGs over time and voting behavior shows: the chance to get re-elected as a government significantly increases for progress made towards SDG 5 (Gender Equality). Notable differences are also found for high-income vs. low-income countries. The fact that governments are rewarded at the ballot box for successful action towards gender equality is encouraging, while the mechanisms behind other SDG areas deserve more research.
\end{abstract}

Keywords: sustainable development goals; sustainability; voting behavior; re-election; political economy; economic voting; gender equality

\section{Introduction}

The Agenda 2030, with its 17 Sustainable Development Goals, is the long-term policy framework that 193 UN member states have pledged to fulfil [1]. It consists of ambitious goals and targets from the economic, social and environmental sphere [2,3]. In the UN document, the Heads of State and Government declared that they will be "working tirelessly for the full implementation of the Agenda" (ibid.: 4). At the same time, however, governments often aim to pursue a political path that ensures the broadest possible support from voters in order to follow the will of the democratic majority but also with a view to get re-elected. This might result in a conflict of interest. Moreover, public budgets are limited, and the allocation of resources therefore has to reflect certain political preferences over issues that are deemed less important. Finally, some of the 17 Sustainable Development Goals (SDGs) are in conflict with each other and constitute trade-offs [2,3], making the pursuit of the Agenda 2030 a complex undertaking for governments. The question arises, consequently, as to how the country performance in each SDG over time relates to voting behavior, as this remains an important research gap in the literature. The objective of our study is therefore to examine the relationship between SDGs progress and the likelihood of re-election. In other words, does progress on the SDGs increase or decrease the chance for an incumbent government's re-election (and if so, in which SDGs)?

Scholars have sought to explain voting behavior with numerous approaches over the years. As probably the most well-known theoretical macro-level approach to explain voting behavior, 
the economic voting hypothesis [4-6] states that voters reward the government at the ballot box if the economy is doing better than before its term, and they punish the government if the economy is doing worse, respectively. Different versions of the hypothesis emphasize, for example, a retrospective or a prospective tendency of the voter ([4] vs. [5]). By now, a large body of empirical studies was established which looks at the evidence for or against such a hypothesis (for an overview of empirical studies, see [7-12]).

Overall, there seems to be empirical evidence supporting the economic voting hypothesis, independent of specific estimation choices of dependent or (lagged) independent variables. This support is found in the many studies about developed economies but there is also more and more empirical evidence from developing countries (ibid.). Macroeconomic factors, which are reported to have an influence on government re-election, are GDP per capita (positive), unemployment (negative), and inflation (negative). As [7] highlights, voters do take into account other aspects when voting, but the literature suggests that economic factors have a higher weight on their voting decision.

Evidence regarding other macro-level factors' influence on voting behavior remains scarce, especially in a broader perspective of economic, social and environmental concerns. Recently, more and more scholars are beginning to look at other factors than economic ones, i.e., wars [13], natural disasters and subsequent beneficial policies [14], social pacts and legislative reform [15,16], income inequality [17], subjective well-being [18]. What is still missing, however, is a study that systematically examines the economic, social and environmental performance of countries over time, and investigates how this performance affects the chances of a government to get re-elected. This paper closes this gap with an examination of 124 countries, making use of the Agenda 2030 and the 17 SDGs as a comprehensive framework that governments have pledged to achieve. While prior studies only examine the effect of one or selected issues on the chances for re-election, our investigation makes use of the systematic comparison of the 17 key issues that lie behind the SDGs (see Appendix B for a full list of all 17 SDGs).

\section{Method and Data}

\subsection{Method}

This paper analyses whether the macro-level performance in various domains, from economic over social to environmental, has an effect on the re-election of incumbent governments. While the economic voting hypothesis suggests that voters re-elect or punish governments based on economic outcomes, this paper investigates whether voters apply similar reasoning to other factors.

Inspired by the macro-economic literature on economic voting [7-12], this analysis specifically investigates the effect of policy outcomes on re-election rather than on incumbent vote or seat shares. The following logit model is estimated using the software STATA v16:

$$
\text { Reelect }_{i t}=\alpha+\beta_{1} \Delta S D G_{-} x_{i 2015-2010}+\beta_{2} g d p p c_{\Delta t}+\beta_{3} u n e m p_{\Delta t}+\beta_{4} S_{i}+\varepsilon_{i t}
$$

where Reelect $_{i t}$ is a dummy variable indicating whether the major incumbent party of the government coalition is reelected or not, $\Delta S D G \_x$ is the change in the respective SDG Indicator (1-17), gdppc is the percentage change in GDP per capita over the preceding election term, unemp is the percentage point change in the unemployment rate over the preceding election term, and $S$ is a dummy for the type of electoral system. The dummy for the electoral system is coded 0 for presidential systems, 1 for assembly-elected presidential systems, and 2 for parliamentary systems. GDP per capita growth and the unemployment rate are used as control variables of the development of the economy, as these two variables are found to be the most important economic factors in previous studies [12]. The regression table is available in the results section, tables with additional specifications can be found in the Appendix A.

In this analysis, a medium-term view is adopted with regard to the time period covered when evaluating whether voters attribute the outcome of policies to incumbent parties. The authors of [14] 
find evidence that voters positively associate beneficial policies with incumbent parties for five to even seven years. Underlying this analysis is therefore the assumption that voters attribute policy outcomes, which are reflected by changes in the SDG indicators, to the incumbent parties over the period of several years.

\subsection{Data}

The analysis of this paper makes use of the combination of two datasets, the SDG Index database for measuring the progress in various economic, social, and environmental policy spheres [19], and the database of political institutions from the Inter-American Development Bank [20] for measuring election outcomes, supplemented with additional election results for the years 2017 and 2018.

The SDG Index database provides globally available data at a country level on SDGs indicators [19]. It contains data for 193 countries, with up to 111 indicators per country on the SDGs. Detailed information, including the full list of indicators and the raw data used here, are available at www. sdgindex.org (see also [21] for the methodology). Indicators for each goal are normalized and aggregated into a goal score, which, in the end, is again aggregated into an SDG Index score for each country using an equal weighting for all 17 SDGs. Data with a comprehensive country coverage of the period from 2010 to 2015 is available for 15 out of 17 SDGs (missing SDG 10 Reducing Inequalities and SDG 12 Sustainable Production and Consumption).

The database of political institutions covers the election results for 181 countries over the period from 1975 until 2016. We supplement this database with an online search of election results for 2017 and 2018 making use of the latest election results in each country if it took place in or after 2014. 'Being re-elected' is coded as the major coalition incumbent party being re-elected into government. Two points should be kept in mind. First, the analysis only covers elections as coded in the dataset, which means that it does not take into account changes in governments that happen without elections. Second, it codes re-election in legislative and executive elections only if they have an effect on the number of seats of the government. This means, if executive elections do not affect the number of seats of parties, they are not considered. Technically speaking, this also implies that if in an election the number of seats of the government stayed the same, this election is omitted from the analysis.

Combining the two databases yields a dataset that covers 124 countries. As additional control variables, data on unemployment rates and GDP per capita growth is added from the World Bank database (https://data.worldbank.org). The last update of the data collection from all databases took place on 31 June 2019. Table 1 provides summary statistics for all variables used in the analysis. A list of the countries covered in this study is available in an online appendix.

\section{Results}

Table 1 summarizes the descriptive statistics of the variables used in this analysis. With regard to the dependent variable (incumbent government being re-elected), there is a balanced mix of incumbents securing re-election and those suffering electoral defeat. Progress towards the SDGs has been positive for the countries examined on average for 13 out of the 15 goals for which data is available. Only for goals 11 and 16 has country performance on average deteriorated in recent times. The control variable GDP per capita shows a positive development on average as well, while the unemployment variables shows a negative development on average.

Turning to the regression results in Table 2, it becomes evident that, controlling for GDP per capita, unemployment and the electoral system, only one SDG has a significant effect on a government's chances for re-election: the chance to be re-elected as a government increases for progress in SDG 5 (Gender Equality). No significant relationship can be reported for the other SDGs.

The marginal effect size for this significant SDGs is displayed in Table 3. The marginal effect shows the change in probability for one instant change of the independent variables. In the example of SDG 5, the results show that a one point increase in SDG 5 is associated with a 2 percentage point increase in the probability of being re-elected. 
Table 1. Descriptive statistics.

\begin{tabular}{lcccccc}
\hline & $\mathbf{( 1 )}$ & $\mathbf{( 2 )}$ & $\mathbf{( 3 )}$ & $\mathbf{( 4 )}$ & $\mathbf{( 5 )}$ & $\mathbf{( 6 )}$ \\
\hline \multicolumn{1}{c}{ Variables } & Mean & Median & Sd & Min & Max & N \\
\hline Reelected (dummy) & 0.548 & 0.548 & 0.500 & 0 & 1 & 124 \\
SDG 1 (change) & 2.153 & 2.153 & 7.810 & -31.58 & 26.71 & 123 \\
SDG 2 (change) & 1.096 & 1.096 & 3.665 & -7.059 & 12.96 & 122 \\
SDG 3 (change) & 2.711 & 2.711 & 3.114 & -5.893 & 15.44 & 102 \\
SDG 4 (change) & 0.614 & 0.614 & 10.96 & -34.01 & 39.50 & 124 \\
SDG 5 (change) & 3.791 & 3.791 & 5.362 & -6.917 & 23.16 & 119 \\
SDG 6 (change) & 2.917 & 2.917 & 4.884 & -6.808 & 28.97 & 99 \\
SDG 7 (change) & 1.609 & 1.609 & 3.864 & -24.51 & 17.92 & 123 \\
SDG 8 (change) & 5.527 & 5.527 & 7.593 & -28.94 & 21.22 & 94 \\
SDG 9 (change) & 20.41 & 20.41 & 12.93 & -4.907 & 55.98 & 124 \\
SDG 11 (change) & -0.618 & -0.618 & 6.740 & -22.96 & 10.07 & 100 \\
SDG 13 (change) & 1.415 & 1.415 & 3.648 & -5.960 & 20.39 & 123 \\
SDG 14 (change) & 0.189 & 0.189 & 4.234 & -11.51 & 20.36 & 82 \\
SDG 15 (change) & 1.318 & 1.318 & 5.431 & -2.667 & 33.71 & 98 \\
SDG 16 (change) & -0.269 & -0.269 & 8.554 & -34.05 & 20.79 & 96 \\
SDG 17 (change) & 1.882 & 1.882 & 13.74 & -32.64 & 61.65 & 63 \\
GDP per capita (growth rate & 0.0905 & 0.0905 & 0.106 & -0.281 & 0.397 & 118 \\
over previous election term) & & & & & & \\
Unemployment rate & -0.744 & -0.744 & 1.862 & -6.730 & 5.371 & 120 \\
(percentage point change over & & & & & & \\
previous election term & 1.105 & 1.105 & 0.978 & 0 & 2 & 124 \\
Electoral system (dummy) & & & & & & \\
\hline
\end{tabular}

Table 2. (a) Regression results for a government's chances of re-election. (b) Regression results for a government's chances of re-election.

(a)

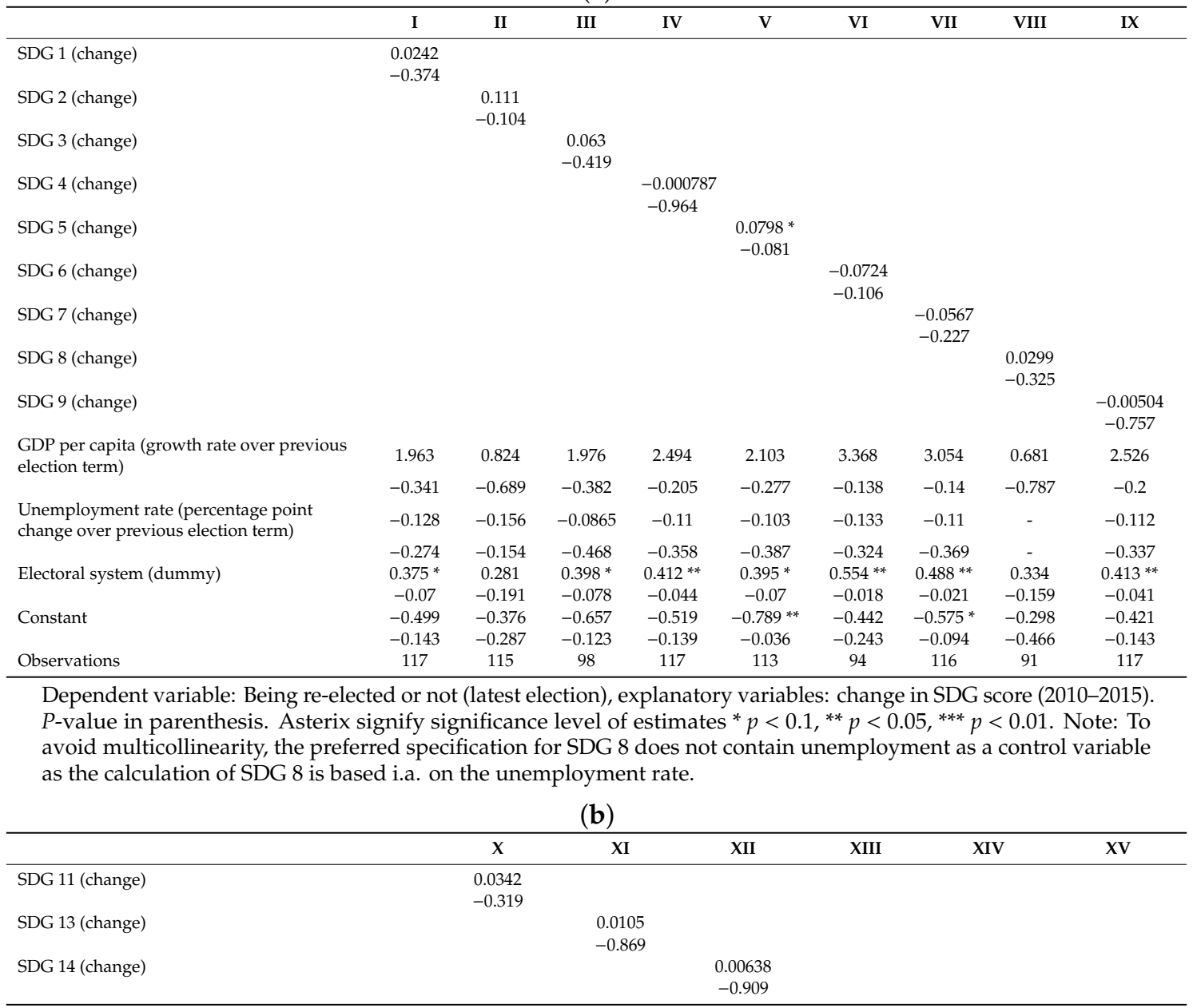


Table 2. Cont.

\begin{tabular}{|c|c|c|c|c|c|c|}
\hline & $X$ & XI & XII & XIII & XIV & $\mathbf{X V}$ \\
\hline SDG 15 (change) & & & & $\begin{array}{l}-0.0497 \\
-0.208\end{array}$ & & \\
\hline SDG 16 (change) & & & & & $\begin{array}{l}-0.0105 \\
-0.713\end{array}$ & \\
\hline SDG 17 (change) & & & & & & $\begin{array}{l}0.0203 \\
-0.267\end{array}$ \\
\hline GDP p.c. (growth rate over previous election term) & $\begin{array}{c}1.468 \\
-0.524\end{array}$ & $\begin{array}{c}2.372 \\
-0.251\end{array}$ & $\begin{array}{c}0.859 \\
-0.723\end{array}$ & $\begin{array}{c}1.488 \\
-0.474\end{array}$ & $\begin{array}{c}0.133 \\
-0.956\end{array}$ & $\begin{array}{l}-3.397 \\
-0.44\end{array}$ \\
\hline $\begin{array}{l}\text { Unemployment rate (percentage point change over } \\
\text { previous election term) }\end{array}$ & -0.0866 & -0.114 & -0.0771 & -0.0842 & -0.117 & $-0.548^{* * *}$ \\
\hline Electoral system (dummy) & $\begin{array}{l}-0.495 \\
0.440^{*} \\
-0.061\end{array}$ & $\begin{array}{c}-0.331 \\
0.418^{*} \\
-0.06\end{array}$ & $\begin{array}{c}-0.54 \\
0.252 \\
-0.305\end{array}$ & $\begin{array}{c}-0.496 \\
0.375 \\
-0.11\end{array}$ & $\begin{array}{l}-0.385 \\
0.412 * \\
-0.074\end{array}$ & $\begin{array}{c}-0.008 \\
0.438 \\
-0.159\end{array}$ \\
\hline Constant & $\begin{array}{l}-0.396 \\
-0.287\end{array}$ & $\begin{array}{l}-0.543 \\
-0.123\end{array}$ & $\begin{array}{l}-0.299 \\
-0.139\end{array}$ & $\begin{array}{l}-0.328 \\
-0.036\end{array}$ & $\begin{array}{l}-0.202 \\
-0.243\end{array}$ & $\begin{array}{l}-0.411 \\
-0.094\end{array}$ \\
\hline Observations & 115 & 98 & 117 & 113 & 94 & 116 \\
\hline
\end{tabular}

Dependent variable: Being re-elected or not (latest election), explanatory variables: change in SDG score (2010-2015). $P$-value in parenthesis. Asterix signify significance level of estimates ${ }^{*} p<0.1,{ }^{* *} p<0.05,{ }^{* * *} p<0.01$. Note: To avoid multicollinearity, the preferred specification for SDG 8 does not contain unemployment as a control variable as the calculation of SDG 8 is based i.a. on the unemployment rate.

Table 3. Marginal effects.

\begin{tabular}{lc}
\hline SDG 5 (change) & 0.020 \\
GDP per capita (growth rate over previous election term) & $(1.76)^{*}$ \\
& 0.512 \\
Unemployment rate (percentage point change over previous & $(1.07)$ \\
election term & -0.025 \\
Electoral system (dummy) & $(0.85)$ \\
1. Default: Parliamentary & 0.000 \\
2. Assembly. Elect. President & 0.136 \\
3. Presidential & $(0.53)$ \\
Number of observations & 0.194 \\
Z-scores in parenthesis. Asterix signify significance level of estimates $\left(^{*} 10^{*},{ }^{* *} 5 \%,{ }^{* * *} 1 \%\right)$
\end{tabular}

For an increase in the score of SDG 5 indicator of 10 points, the probability of governments to get re-elected rises by roughly 20 percentage points, all else equal.

Figures 1 and 2 show the conditional probability of getting re-elected with various magnitudes of changes in the SDG 5 as well as for GDP per capita as a comparison, and thereby elaborate in more detail on the results. The first panel gives insights about SDG 5: All other variables taken at their mean values, no progress in SDG 5 implies a probability of re-election of roughly $50 \%$ in parliamentary systems. However, if progress is made in achieving SDG 5, say there is an increase of 5 points on the SDG 5 indicator, the probability of being re-elected, all else equal, lies by $57 \%$.

Finally, Table 4 shows results for high-income and low-income countries (using an interaction term) separately and points out notable differences. For example, for SDG 3, there is a positive association between progress in the goal and getting re-elected for low-income countries, while there is no significant relationship for high-income countries. As another example, the positive effect of SDG 5 is much smaller for high-income countries (although still positive and significant), which means that the aforementioned result for the whole sample is mainly driven by low-income countries. For SDG 6, there is a significant negative association for high-income countries, meaning that governments are actually punished at the ballot box for having achieved progress. Significant effects are also found for SDGs 9, 13, 15. 


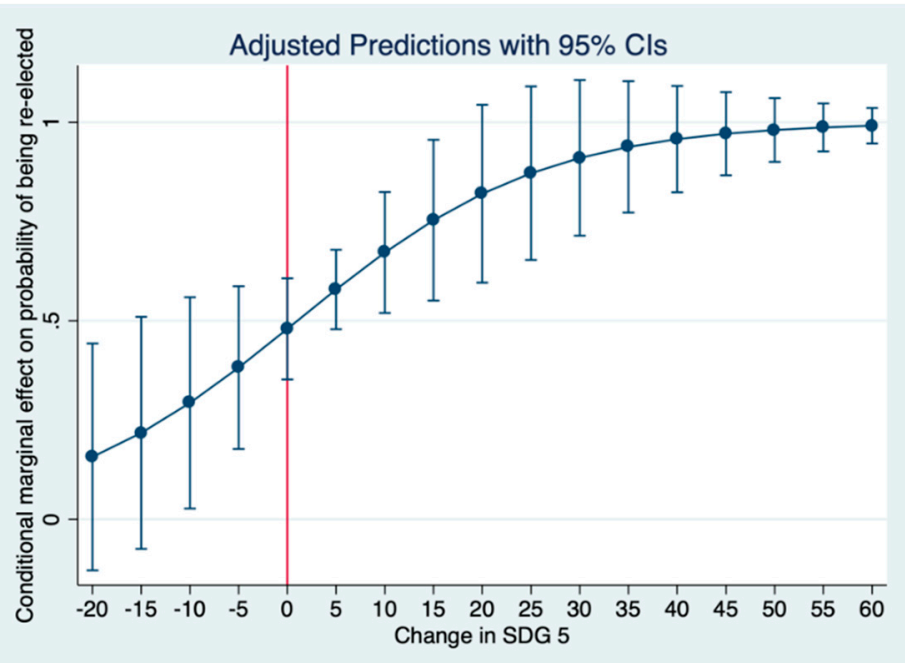

Figure 1. Conditional probability of getting re-elected with various magnitudes of changes in Sustainable Development Goal (SDG) 5.

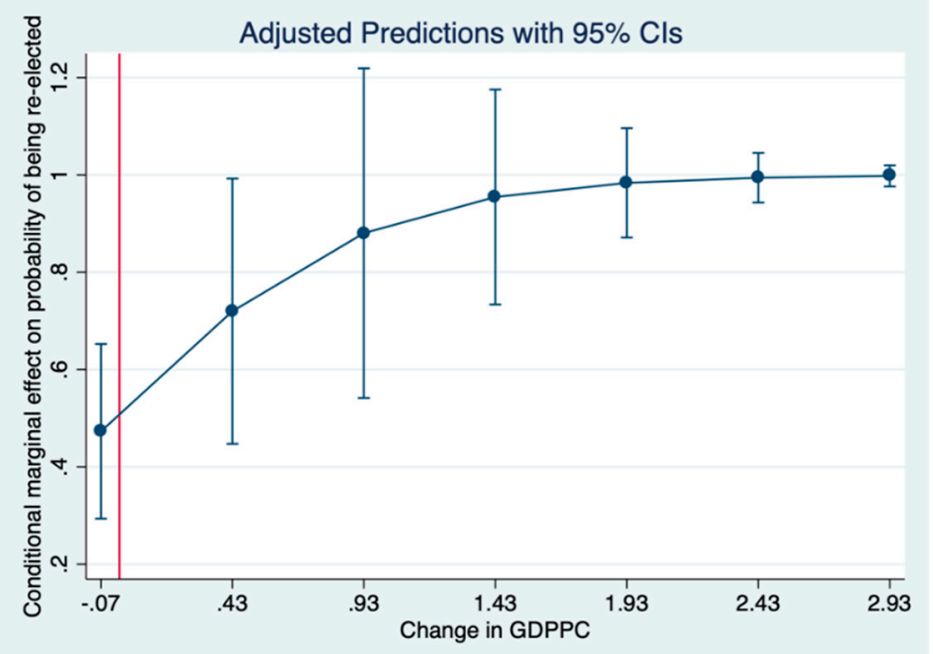

Figure 2. Conditional probability of getting re-elected with various magnitudes of changes in GDP per capita.

Table 4. (a) Regression results for a government's chances for re-election-interaction effect with development. (b) Regression results for a government's chances for re-election-interaction effect with development.

(a)

\begin{tabular}{|c|c|c|c|c|c|c|c|}
\hline & I & II & III & IV & V & VI & VII \\
\hline SDG 1 (change) & $\begin{array}{c}0.00958 \\
-0.812\end{array}$ & & & & & & \\
\hline SDG $1^{*}$ dev.status & $\begin{array}{l}0.0377 \\
-0.524\end{array}$ & & & & & & \\
\hline SDG 2 (change) & & $\begin{array}{c}0.037 \\
-0.717\end{array}$ & & & & & \\
\hline SDG $2^{*}$ dev.status & & $\begin{array}{c}0.192 \\
-0.197\end{array}$ & & & & & \\
\hline SDG 3 (change) & & & $\begin{array}{l}0.244^{*} \\
-0.096\end{array}$ & & & & \\
\hline SDG $3^{*}$ dev.status & & & $\begin{array}{l}-0.265 \\
-0.113\end{array}$ & & & & \\
\hline SDG 4 (change) & & & & -0.00716 & & & \\
\hline
\end{tabular}


Table 4. Cont.

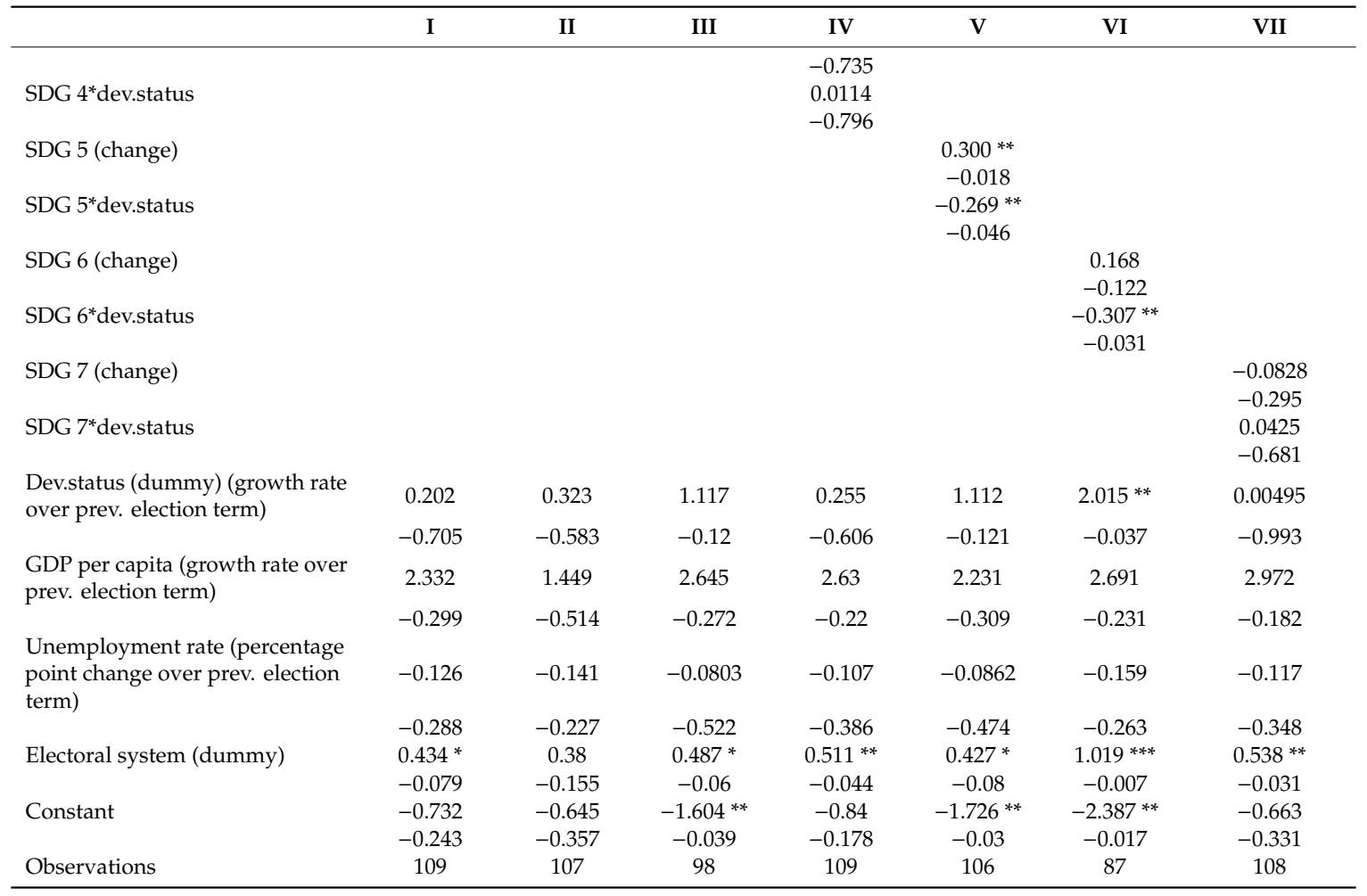

Dependent variable: Being re-elected or not (latest election), explanatory variables: change in SDG score (2010-2015) including an interaction term with the development status of the countries (dummy equals 1 for high-income countries, dummy equals 0 for low-income countries). $P$-value in parenthesis. Asterix signify significance level of estimates ${ }^{*} p<0.1,{ }^{* *} p<0.05,{ }^{* * *} p<0.01$. Note: To avoid multicollinearity, the preferred specification for SDG 8 does not contain unemployment as a control variable as the calculation of SDG 8 is based i.a. on the unemployment rate.

(b)

\begin{tabular}{|c|c|c|c|c|c|c|c|c|}
\hline & VIII & IX & $X$ & XI & XII & XIII & XIV & $\mathbf{X V}$ \\
\hline SDG 8 (change) & $\begin{array}{l}0.0248 \\
-0.653\end{array}$ & & & & & & & \\
\hline SDG $8^{*}$ dev.status & $\begin{array}{c}0.00851 \\
-0.896\end{array}$ & & & & & & & \\
\hline SDG 9 (change) & & $\begin{array}{c}-0.0593 \text { * } \\
-0.053\end{array}$ & & & & & & \\
\hline SDG 11 (change) & & & $\begin{array}{l}0.0144 \\
-0.747\end{array}$ & & & & & \\
\hline SDG $11^{*}$ dev.status & & & $\begin{array}{l}0.0385 \\
-0.601\end{array}$ & & & & & \\
\hline SDG 13 (change) & & & & $\begin{array}{l}-0.802 \\
-0.107\end{array}$ & & & & \\
\hline SDG 15 (change) & & & & & & $\begin{array}{c}-0.0978 \text { * } \\
-0.076\end{array}$ & & \\
\hline SDG $15^{*}$ dev.status & & & & & & $\begin{array}{l}0.0934 \\
-0.267\end{array}$ & & \\
\hline SDG 16 (change) & & & & & & & $\begin{array}{c}0.00273 \\
-0.958\end{array}$ & \\
\hline SDG $16^{*}$ dev.status & & & & & & & $\begin{array}{c}-0.0205 \\
-0.736\end{array}$ & \\
\hline SDG 17 (change) & & & & & & & & $\begin{array}{l}0.0339 \\
-0.182\end{array}$ \\
\hline
\end{tabular}


Table 4. Cont.

\begin{tabular}{|c|c|c|c|c|c|c|c|c|}
\hline & VIII & IX & $\mathbf{X}$ & $\mathbf{X I}$ & XII & XIII & XIV & $\mathbf{X V}$ \\
\hline & & & & & & & & -0.617 \\
\hline \multirow{2}{*}{$\begin{array}{l}\text { Dev.status (dummy) (growth } \\
\text { rate over previous election } \\
\text { term) }\end{array}$} & -0.371 & -0.458 & 0.277 & 0.187 & -0.338 & 0.272 & -0.0378 & -0.334 \\
\hline & -0.619 & -0.643 & -0.588 & -0.708 & -0.616 & -0.632 & -0.949 & -0.699 \\
\hline $\begin{array}{l}\text { GDP per capita (growth rate } \\
\text { over previous election term) }\end{array}$ & 0.0546 & 3.782 & 1.898 & 2.403 & -0.901 & 2.181 & 0.13 & -4.974 \\
\hline change/previous election term) & & -0.385 & -0.639 & -0.411 & -0.448 & -0.615 & -0.371 & -0.011 \\
\hline \multirow[t]{2}{*}{ Electoral system (dummy) } & 0.247 & $0.533^{* *}$ & 0.498 * & $0.537^{* *}$ & 0.155 & 0.442 & 0.401 & 0.291 \\
\hline & -0.39 & -0.046 & -0.059 & -0.042 & -0.608 & -0.102 & -0.144 & -0.429 \\
\hline \multirow[t]{2}{*}{ Constant } & 0.0953 & -0.0374 & -0.674 & -0.836 & 0.144 & -0.631 & -0.158 & 0.105 \\
\hline & -0.913 & -0.962 & -0.293 & -0.2 & -0.865 & -0.356 & -0.831 & -0.923 \\
\hline Observations & 91 & 109 & 96 & 108 & 77 & 94 & 92 & 57 \\
\hline
\end{tabular}

Dependent variable: Being re-elected or not (latest election), explanatory variables: change in SDG score (2010-2015) including an interaction term with the development status of the countries (dummy equals 1 for high-income countries, dummy equals 0 for low-income countries). $P$-value in parenthesis. Asterix signify significance level of estimates ${ }^{*} p<0.1,{ }^{* *} p<0.05,{ }^{* * *} p<0.01$. Note: To avoid multicollinearity, the preferred specification for SDG 8 does not contain unemployment as a control variable as the calculation of SDG 8 is based i.a. on the unemployment rate.

\section{Discussion}

As a comprehensive approach to explain voting behavior, this paper applied for the first time a broader perspective of economic, social and environmental concerns. The Agenda 2030 with its SDGs was used in the first analysis of performance on the SDGs over time and subsequent voting behavior for 124 countries to estimate the likelihood for governments to stay in power. When looking at the whole sample, the results have shown that only one SDG out of 15 has a significant effect on the chance to get re-elected as a government. The chances for the incumbents at the ballot box increase significantly for progress made towards SDG 5 (Gender Equality). For an improvement in the SDG 5 score of 10 points out of 100 , the probability of a government to get re-elected rises by roughly 20 percentage points. No significant relationships were found with regard to the remaining 14 SDGs tested, including SDG 8, for the whole sample. It can therefore be said that the data do not support the economic voting hypothesis if the economic situation of the countries under study is defined as in SDG 8 (Decent Work and Economic Growth); for an overview of empirical studies on economic voting, see [7-12]. A more fine-grained analysis of high-income vs. low-income countries brought to light additional results for selected SDGs, such as the positive effect of getting re-elected on progress in SDG 3 (Health and Well-Being) for low-income countries. It has also shown that the finding on gender equality is largely driven by low-income countries.

This study is limited by the availability of data, which ought to be tackled by data providers in the future. In particular, it would be desirable to expand the global indicator set available to measure the SDGs (especially for the multi-faceted goals that require numerous indicators in order to adequately capture all sub-targets), close data gaps on the missing SDGs, and to have time-series data with 2015 (the year of the adoption of the Agenda 2030) as the baseline year.

In the end, the results show that voters do not take into account the country's development in all goals in their decision, and they illustrate which goals and underlying issues matter most for voters in terms of re-electing their respective government. One of the SDGs seems to be felt in a more immediate manner by voters: achieving gender equality, namely by "end(ing) all forms of discrimination against all women and girls everywhere" (target 5.1) or by "ensur(ing) women's full and effective participation and equal opportunities for leadership at all levels of decision-making in political, economic and public life" (target 5.5) [1] (see Table 5 for the complete list of targets). Future analyses ought to examine the underlying mechanisms further, e.g., by examining with more fine-grained data whether this result is driven especially by female voters supporting incumbent governments that have contributed to significant progress in this goal. As the extent to which gender equality is realized varies considerably across the globe, the targets also apply to a varying degree to the regions and countries of the globe. 
Certain targets, especially around family planning, are more relevant for a populous low-income country than for a high-income country. Future research to examine these issues in more depth should take such a variation into account.

Table 5. SDG 5: Achieve gender equality and empower all women and girls.

\begin{tabular}{cl}
\hline 5.1 & End all forms of discrimination against all women and girls everywhere \\
\hline 5.2 & $\begin{array}{l}\text { Eliminate all forms of violence against all women and girls in the public and private spheres, including trafficking and } \\
\text { sexual and other types of exploitation }\end{array}$ \\
\hline 5.3 & $\begin{array}{l}\text { Eliminate all harmful practices, such as child, early and forced marriage and female genital mutilation } \\
\text { Recognize and value unpaid care and domestic work through the provision of public services, infrastructure and social } \\
\text { protection policies and the promotion of shared responsibility within the household and the family as nationally } \\
\text { appropriate }\end{array}$ \\
\hline 5.5 & $\begin{array}{l}\text { Ensure women's full and effective participation and equal opportunities for leadership at all levels of decision-making } \\
\text { in political, economic and public life }\end{array}$ \\
\hline 5.6 & $\begin{array}{l}\text { Ensure universal access to sexual and reproductive health and reproductive rights as agreed in accordance with the } \\
\text { Programme of Action of the International Conference on Population and Development and the Beijing Platform for } \\
\text { Action and the outcome documents of their review conferences }\end{array}$ \\
\hline $5 . \mathrm{a}$ & $\begin{array}{l}\text { Undertake reforms to give women equal rights to economic resources, as well as access to ownership and control over } \\
\text { land and other forms of property, financial services, inheritance and natural resources, in accordance with national laws }\end{array}$ \\
\hline $5 . b$ & $\begin{array}{l}\text { Enhance the use of enabling technology, in particular information and communications technology, to promote the } \\
\text { empowerment of women }\end{array}$ \\
\hline $5 . c$ & $\begin{array}{l}\text { Adopt and strengthen sound policies and enforceable legislation for the promotion of gender equality and the } \\
\text { empowerment of all women and girls at all levels }\end{array}$ \\
\hline & $\quad$ Source: UN (2015).
\end{tabular}

Source: UN (2015).

In conclusion, while the fact that governments are rewarded at the ballot box for successful action most notably on gender equality appears to be a justified and encouraging sign, the reasons behind the lack of significant associations with SDG progress in many other areas deserve more research in the future. For instance, the results provoke the question as to whether environmental concerns, as captured in many SDGs, are getting enough and adequate attention in political discourses around elections. Moreover, progress on the environmental goals in particular has a social dimension, as recent analyses on the emergence of synergies and trade-offs between the SDGs show [3]. This fact is also illustrated in contemporary public discourses, for example, around the Yellow Vest protests in France. When the government tried to introduce new measures on climate protection, these were perceived to hit the poor and middle-class economically in a disproportionate manner, and they were met with civil unrest. More research into the public perception of such synergies and trade-offs between the SDGs, particularly in relation to voting behavior, would illuminate these issues further. After all, a successful policy framework for the future will be one that enables synergies between economic, social and environmental progress and ensures that environmental protection does not come at the expense of the poorer parts of society.

Author Contributions: Conceptualization, C.K. and V.Z.; methodology, C.K. and V.Z.; formal analysis, C.K. and V.Z.; data curation, V.Z.; writing-original draft preparation, C.K. and V.Z.; writing-review and editing, C.K.; visualization, V.Z.; supervision, C.K.; project administration, C.K.; funding acquisition, C.K. All authors have read and agreed to the published version of the manuscript.

Funding: Funding was provided by Bertelsmann Stiftung.

Conflicts of Interest: The authors declare no conflict of interest. 


\section{Appendix A}

Table A1. Full estimation table with additional specifications

\begin{tabular}{|c|c|c|c|c|c|c|c|c|c|c|c|c|}
\hline & Baseline & $\begin{array}{c}\text { Baseline+ } \\
\text { System }\end{array}$ & $\begin{array}{c}\text { Baseline+ } \\
\text { System+ } \\
\text { Gdppc }\end{array}$ & $\begin{array}{l}\text { Baseline+ } \\
\text { Full } \\
\text { Controls }\end{array}$ & Baseline & $\begin{array}{l}\text { Baseline+ } \\
\text { System }\end{array}$ & $\begin{array}{c}\text { Baseline+ } \\
\text { System+ } \\
\text { Gdppc }\end{array}$ & $\begin{array}{l}\text { Baseline+ } \\
\text { Full } \\
\text { Controls }\end{array}$ & Baseline & $\begin{array}{l}\text { Baseline+ } \\
\text { System }\end{array}$ & $\begin{array}{c}\text { Baseline+ } \\
\text { System+ } \\
\text { Gdppc }\end{array}$ & $\begin{array}{c}\text { Baseline+ } \\
\text { Full } \\
\text { Controls }\end{array}$ \\
\hline & Re-elected & Re-elected & Re-elected & Re-elected & Re-elected & Re-elected & Re-elected & Re-elected & Re-elected & Re-elected & Re-elected & Re-elected \\
\hline SDG 1 (change) & $\begin{array}{l}0.0348 \\
-0.178\end{array}$ & $\begin{array}{l}0.0256 \\
-0.327\end{array}$ & $\begin{array}{c}0.02 \\
-0.453\end{array}$ & $\begin{array}{l}0.0242 \\
-0.374\end{array}$ & & & & & & & & \\
\hline SDG 2 (change) & & & & & $\begin{array}{l}0.139 * * \\
-0.029\end{array}$ & $\begin{array}{l}0.117 * \\
-0.065\end{array}$ & $\begin{array}{l}0.0973 \\
-0.136\end{array}$ & $\begin{array}{c}0.111 \\
-0.104\end{array}$ & & & & \\
\hline SDG 3 (change) & & & & & & & & & $\begin{array}{l}0.0527 \\
-0.461\end{array}$ & $\begin{array}{l}0.0538 \\
-0.428\end{array}$ & $\begin{array}{c}0.063 \\
-0.414\end{array}$ & $\begin{array}{c}0.063 \\
-0.419\end{array}$ \\
\hline $\begin{array}{l}\text { GDP per capita } \\
\text { (growth rate over } \\
\text { previous election } \\
\text { term) }\end{array}$ & & & 2.271 & 1.963 & & & 1.39 & 0.824 & & & 2.472 & 1.976 \\
\hline Unemployment & & & -0.24 & -0.341 & & & -0.465 & -0.689 & & & -0.258 & -0.382 \\
\hline $\begin{array}{l}\text { rate (p.p. } \\
\text { change/previous } \\
\text { election term }\end{array}$ & & & & $\begin{array}{l}-0.128 \\
-0.274\end{array}$ & & & & $\begin{array}{l}-0.156 \\
-0.154\end{array}$ & & & & $\begin{array}{l}-0.0865 \\
-0.468\end{array}$ \\
\hline $\begin{array}{l}\text { Electoral system } \\
\text { (dummy) }\end{array}$ & & $0.360 *$ & $0.353 *$ & 0.375 * & & 0.266 & 0.252 & 0.281 & & $0.390 *$ & 0.366 & 0.398 * \\
\hline Constant & $\begin{array}{c}0.108 \\
-0.566 \\
\end{array}$ & $\begin{array}{l}-0.062 \\
-0.264 \\
-0.335\end{array}$ & $\begin{array}{l}-0.081 \\
-0.422 \\
-0.21 \\
\end{array}$ & $\begin{array}{l}-0.07 \\
-0.499 \\
-0.143 \\
\end{array}$ & $\begin{array}{l}0.0631 \\
-0.738 \\
\end{array}$ & $\begin{array}{l}-0.186 \\
-0.208 \\
-0.463\end{array}$ & $\begin{array}{l}-0.232 \\
-0.284 \\
-0.418 \\
\end{array}$ & $\begin{array}{l}-0.191 \\
-0.376 \\
-0.287\end{array}$ & $\begin{array}{l}0.0953 \\
-0.728 \\
\end{array}$ & $\begin{array}{l}-0.066 \\
-0.352 \\
-0.334 \\
\end{array}$ & $\begin{array}{l}-0.101 \\
-0.6 \\
-0.161\end{array}$ & $\begin{array}{l}-0.078 \\
-0.657 \\
-0.123 \\
\end{array}$ \\
\hline $\begin{array}{l}\text { Observations } \\
\text { BIC }\end{array}$ & $\begin{array}{c}123 \\
177.1\end{array}$ & $\begin{array}{c}123 \\
178.3\end{array}$ & $\begin{array}{c}118 \\
175.1\end{array}$ & $\begin{array}{c}117 \\
176.9\end{array}$ & $\begin{array}{c}122 \\
170.6\end{array}$ & $\begin{array}{c}122 \\
173.6\end{array}$ & $\begin{array}{c}116 \\
171.1\end{array}$ & $\begin{array}{c}115 \\
172.4\end{array}$ & $\begin{array}{c}102 \\
148.6\end{array}$ & $\begin{array}{c}102 \\
149.7\end{array}$ & $\begin{array}{c}98 \\
148.2\end{array}$ & $\begin{array}{c}98 \\
152.2\end{array}$ \\
\hline SDG 4 (change) & $\begin{array}{l}-0.0153 \\
-0.361\end{array}$ & $\begin{array}{l}-0.0112 \\
-0.498\end{array}$ & $\begin{array}{l}-0.00478 \\
-0.777\end{array}$ & $\begin{array}{c}-0.000787 \\
-0.964\end{array}$ & & & & & & & & \\
\hline SDG 5 (change) & & & & & $\begin{array}{l}0.0941 * * \\
-0.046\end{array}$ & $\begin{array}{l}0.0886^{*} \\
-0.053\end{array}$ & $\begin{array}{l}0.0804^{*} \\
-0.078\end{array}$ & $\begin{array}{c}0.0798^{*} \\
-0.081\end{array}$ & & & & \\
\hline SDG 6 (change) & & & & & & & & & $\begin{array}{l}-0.0244 \\
-0.536\end{array}$ & $\begin{array}{l}-0.0423 \\
-0.343\end{array}$ & $\begin{array}{l}-0.0638 \\
-0.147\end{array}$ & $\begin{array}{l}-0.0724 \\
-0.106\end{array}$ \\
\hline $\begin{array}{l}\text { GDP p.c. (growth } \\
\text { rate over previous } \\
\text { election term) }\end{array}$ & & & 2.61 & 2.494 & & & 2.526 & 2.103 & & & 3.265 & 3.368 \\
\hline & & & -0.163 & -0.205 & & & -0.179 & -0.277 & & & -0.125 & -0.138 \\
\hline
\end{tabular}


Table A1. Cont.

\begin{tabular}{|c|c|c|c|c|c|c|c|c|c|c|c|c|}
\hline & Baseline & $\begin{array}{c}\text { Baseline+ } \\
\text { System }\end{array}$ & $\begin{array}{c}\text { Baseline+ } \\
\text { System+ } \\
\text { Gdppc }\end{array}$ & $\begin{array}{c}\text { Baseline+ } \\
\text { Full } \\
\text { Controls }\end{array}$ & Baseline & $\begin{array}{c}\text { Baseline+ } \\
\text { System }\end{array}$ & $\begin{array}{c}\text { Baseline+ } \\
\text { System+ } \\
\text { Gdppc }\end{array}$ & $\begin{array}{l}\text { Baseline+ } \\
\text { Full } \\
\text { Controls }\end{array}$ & Baseline & $\begin{array}{c}\text { Baseline+ } \\
\text { System }\end{array}$ & $\begin{array}{c}\text { Baseline+ } \\
\text { System+ } \\
\text { Gdppc }\end{array}$ & $\begin{array}{c}\text { Baseline+ } \\
\text { Full } \\
\text { Controls }\end{array}$ \\
\hline $\begin{array}{l}\text { Unemployment } \\
\text { rate (percentage }\end{array}$ & & & & & & & & & & & & \\
\hline $\begin{array}{l}\text { point change over } \\
\text { previous election }\end{array}$ & & & & -0.11 & & & & -0.103 & & & & -0.133 \\
\hline & & & & -0.358 & & & & -0.387 & & & & -0.324 \\
\hline $\begin{array}{l}\text { Electoral system } \\
\text { (dummy) }\end{array}$ & & $0.397^{* *}$ & $0.386^{*}$ & $0.412^{* *}$ & & 0.377 * & 0.347 * & 0.395 * & & $0.496^{* *}$ & $0.533^{* *}$ & $0.554^{* *}$ \\
\hline Constant & $\begin{array}{c}0.205 \\
-0.259\end{array}$ & $\begin{array}{l}-0.037 \\
-0.23 \\
-0.405\end{array}$ & $\begin{array}{c}-0.051 \\
-0.44 \\
-0.195\end{array}$ & $\begin{array}{l}-0.044 \\
-0.519 \\
-0.139\end{array}$ & $\begin{array}{c}-0.15 \\
-0.528\end{array}$ & $\begin{array}{l}-0.062 \\
-0.552^{*} \\
-0.084\end{array}$ & $\begin{array}{c}-0.099 \\
-0.705^{*} \\
-0.058\end{array}$ & $\begin{array}{c}-0.07 \\
-0.789 * * \\
-0.036\end{array}$ & $\begin{array}{c}0.377 \\
-0.112\end{array}$ & $\begin{array}{l}-0.028 \\
-0.101 \\
-0.748\end{array}$ & $\begin{array}{l}-0.023 \\
-0.362 \\
-0.33\end{array}$ & $\begin{array}{l}-0.018 \\
-0.442 \\
-0.243\end{array}$ \\
\hline Observations & 124 & 124 & 118 & 117 & 119 & 119 & 113 & 113 & 99 & 99 & 95 & 94 \\
\hline BIC & 179.5 & 179.9 & 175.7 & 177.7 & 167.3 & 168.4 & 164.5 & 168.4 & 143.8 & 143.1 & 139.7 & 141.1 \\
\hline SDG 7 (change) & $\begin{array}{l}-0.0196 \\
-0.649\end{array}$ & $\begin{array}{l}-0.0411 \\
-0.396\end{array}$ & $\begin{array}{l}-0.0623 \\
-0.181\end{array}$ & $\begin{array}{l}-0.0567 \\
-0.227\end{array}$ & & & & & & & & \\
\hline SDG 8 (change) & & & & & $\begin{array}{l}0.0461 \\
-0.114\end{array}$ & $\begin{array}{l}0.0344 \\
-0.239\end{array}$ & $\begin{array}{l}0.0299 \\
-0.325\end{array}$ & $\begin{array}{c}0.0291 \\
-0.34\end{array}$ & & & & \\
\hline SDG 9 (change) & & & & & & & & & $\begin{array}{c}-0.0113 \\
-0.417\end{array}$ & $\begin{array}{c}-0.0106 \\
-0.478\end{array}$ & $\begin{array}{c}-0.00617 \\
-0.707\end{array}$ & $\begin{array}{c}-0.00504 \\
-0.757\end{array}$ \\
\hline $\begin{array}{l}\text { GDP p.c. (growth } \\
\text { rate over previous } \\
\text { election term) }\end{array}$ & & & 3.232 & 3.054 & & & 0.681 & -0.358 & & & 2.699 & 2.526 \\
\hline $\begin{array}{l}\text { Unemployment } \\
\text { rate (percentage }\end{array}$ & & & -0.1 & -0.14 & & & -0.787 & -0.895 & & & -0.15 & -0.2 \\
\hline $\begin{array}{l}\text { point change over } \\
\text { previous election } \\
\text { term) }\end{array}$ & & & & -0.11 & & & & -0.152 & & & & -0.112 \\
\hline & & & & -0.369 & & & & -0.27 & & & & -0.337 \\
\hline $\begin{array}{l}\text { Electoral system } \\
\text { (dummy) }\end{array}$ & & $0.464^{* *}$ & $0.469^{* *}$ & $0.488^{* *}$ & & 0.368 & 0.334 & 0.392 & & $0.409^{* *}$ & $0.390 * *$ & $0.413 * *$ \\
\hline Constant & $\begin{array}{c}0.211 \\
-0.277 \\
\end{array}$ & $\begin{array}{l}-0.02 \\
-0.264 \\
-0.343 \\
\end{array}$ & $\begin{array}{l}-0.021 \\
-0.502 \\
-0.136 \\
\end{array}$ & $\begin{array}{l}-0.021 \\
-0.575 * \\
-0.094\end{array}$ & $\begin{array}{l}0.0514 \\
-0.847 \\
\end{array}$ & $\begin{array}{l}-0.104 \\
-0.282 \\
-0.394 \\
\end{array}$ & $\begin{array}{l}-0.159 \\
-0.298 \\
-0.466 \\
\end{array}$ & $\begin{array}{l}-0.105 \\
-0.379 \\
-0.351 \\
\end{array}$ & $\begin{array}{c}0.425 \\
-0.209 \\
\end{array}$ & $\begin{array}{l}-0.031 \\
-0.0334 \\
-0.935 \\
\end{array}$ & $\begin{array}{l}-0.047 \\
-0.328 \\
-0.48 \\
\end{array}$ & $\begin{array}{l}-0.041 \\
-0.421 \\
-0.372 \\
\end{array}$ \\
\hline Observations & 123 & 123 & 117 & 116 & 94 & 94 & 91 & 91 & 124 & 124 & 118 & 117 \\
\hline $\mathrm{BIC}$ & 179 & 177.9 & 172.6 & 174.6 & 134.7 & 136.6 & 138.1 & 141.1 & 179.7 & 179.8 & 175.6 & 177.6 \\
\hline SDG 11 (change) & $\begin{array}{l}0.00059 \\
-0.984\end{array}$ & $\begin{array}{l}0.0169 \\
-0.579\end{array}$ & $\begin{array}{l}0.0365 \\
-0.287\end{array}$ & $\begin{array}{l}0.0342 \\
-0.319\end{array}$ & & & & & & & & \\
\hline
\end{tabular}


Table A1. Cont.

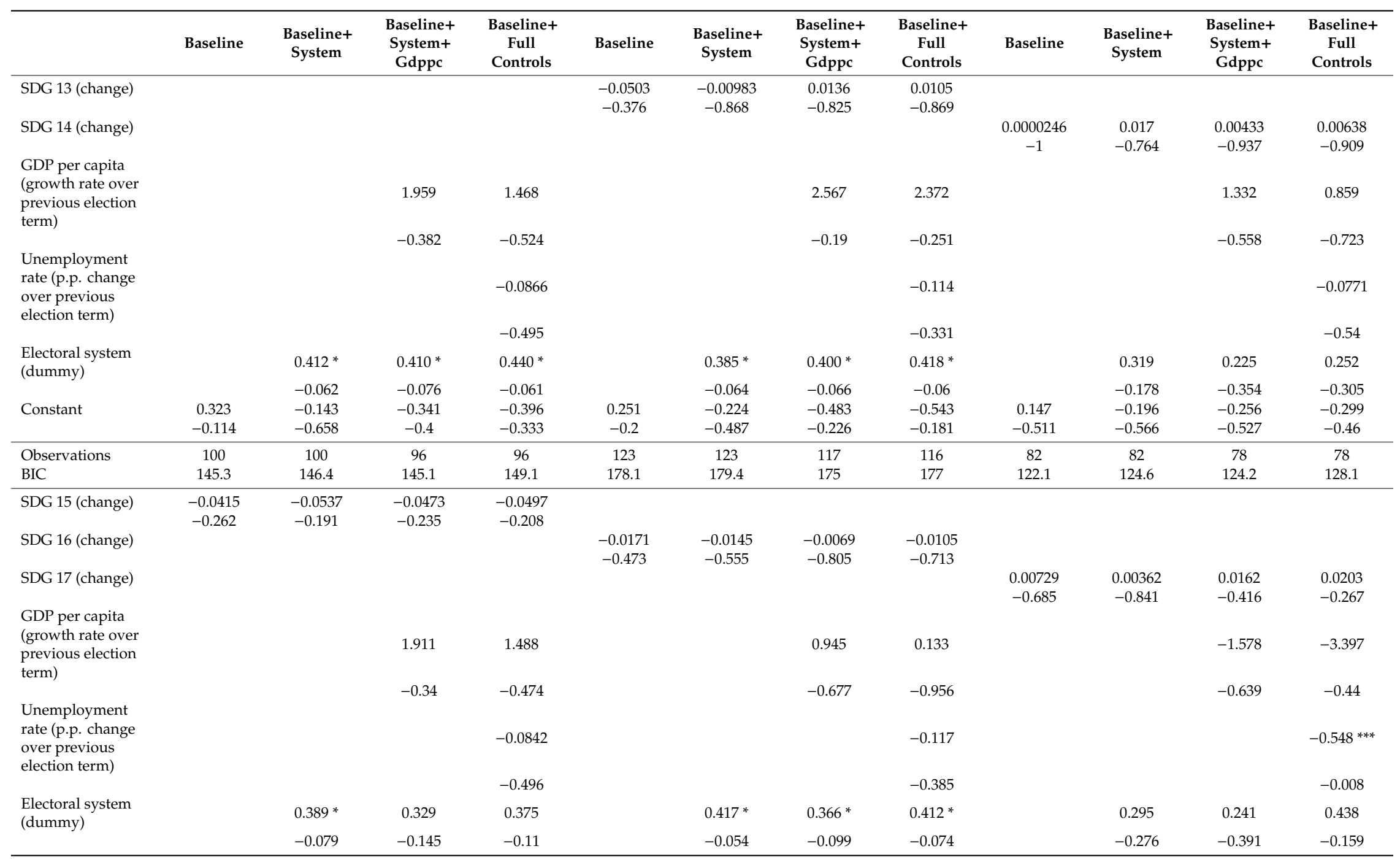


Table A1. Cont.

\begin{tabular}{|c|c|c|c|c|c|c|c|c|c|c|c|c|}
\hline & Baseline & $\begin{array}{l}\text { Baseline+ } \\
\text { System }\end{array}$ & $\begin{array}{c}\text { Baseline+ } \\
\text { System+ } \\
\text { Gdppc }\end{array}$ & $\begin{array}{c}\text { Baseline+ } \\
\text { Full } \\
\text { Controls }\end{array}$ & Baseline & $\begin{array}{c}\text { Baseline+ } \\
\text { System }\end{array}$ & $\begin{array}{c}\text { Baseline+ } \\
\text { System+ } \\
\text { Gdppc }\end{array}$ & $\begin{array}{c}\text { Baseline+ } \\
\text { Full } \\
\text { Controls }\end{array}$ & Baseline & $\begin{array}{c}\text { Baseline+ } \\
\text { System }\end{array}$ & $\begin{array}{c}\text { Baseline+ } \\
\text { System+ } \\
\text { Gdppc }\end{array}$ & $\begin{array}{c}\text { Baseline+ } \\
\text { Full } \\
\text { Controls }\end{array}$ \\
\hline Constant & $\begin{array}{c}0.3 \\
-0.156\end{array}$ & $\begin{array}{l}-0.115 \\
-0.716\end{array}$ & $\begin{array}{c}-0.259 \\
-0.49\end{array}$ & $\begin{array}{l}-0.328 \\
-0.394\end{array}$ & $\begin{array}{l}0.377^{*} \\
-0.072\end{array}$ & $\begin{array}{l}-0.0821 \\
-0.793\end{array}$ & $\begin{array}{l}-0.136 \\
-0.732\end{array}$ & $\begin{array}{l}-0.202 \\
-0.614\end{array}$ & $\begin{array}{l}0.0819 \\
-0.751\end{array}$ & $\begin{array}{l}-0.218 \\
-0.561\end{array}$ & $\begin{array}{l}0.0732 \\
-0.882\end{array}$ & $\begin{array}{l}-0.411 \\
-0.425\end{array}$ \\
\hline Observations & 98 & 98 & 94 & 94 & 96 & 96 & 92 & 92 & 63 & 63 & 60 & 59 \\
\hline BIC & 142.4 & 143.7 & 143.3 & 147.3 & 138.3 & 139.1 & 139.9 & 143.5 & 95.33 & 98.25 & 97.16 & 92.09 \\
\hline
\end{tabular}

$P$-value in parenthesis. Asterix signify significance level of estimates ${ }^{*} p<0.1,{ }^{* *} p<0.05,{ }^{* * *} p<0.01$.

\section{Appendix B}

Table A2. The 17 Sustainable Development Goals.

\begin{tabular}{ll}
\hline Goal 1. & End poverty in all its forms everywhere \\
\hline Goal 2. & End hunger, achieve food security and improved nutrition and promote sustainable agriculture \\
\hline Goal 3. & Ensure healthy lives and promote well-being for all at all ages \\
\hline Goal 4. & Ensure inclusive and equitable quality education and promote lifelong learning opportunities for all \\
\hline Goal 5. & Achieve gender equality and empower all women and girls \\
\hline Goal 6. & Ensure availability and sustainable management of water and sanitation for all \\
\hline Goal 7 & Ensure access to affordable, reliable, sustainable and modern energy for all \\
\hline Goal 8. & Promote sustained, inclusive and sustainable economic growth, full and productive employment and decent work for all \\
\hline Goal 9. & Build resilient infrastructure, promote inclusive and sustainable industrialization and foster innovation \\
\hline Goal 10. & Reduce inequality within and among countries \\
\hline Goal 11. & Make cities and human settlements inclusive, safe, resilient and sustainable \\
\hline Goal 12. & Ensure sustainable consumption and production patterns \\
\hline Goal 13. & Take urgent action to combat climate change and its impacts \\
\hline Goal 14. & Conserve and sustainably use the oceans, seas and marine resources for sustainable development \\
\hline Goal 15. & $\begin{array}{l}\text { Protect, restore and promote sustainable use of terrestrial ecosystems, sustainably manage forests, combat desertification, and halt and reverse land degradation and halt } \\
\text { biodiversity loss }\end{array}$ \\
\hline Goal 16. & Promote peaceful and inclusive societies for sustainable development, provide access to justice for all and build effective, accountable and inclusive institutions at all levels \\
\hline Goal 17. & Strengthen the means of implementation and revitalize the Global Partnership for Sustainable Development \\
\hline
\end{tabular}




\section{References}

1. United Nations. Transforming Our World: The 2030 Agenda for Sustainable Development. 2015. Available online: http://www.un.org/ga/search/view_doc.asp?symbol=A/RES/70/1\&Lang=E (accessed on 15 February 2020).

2. Pradhan, P.; Costa, L.; Rybski, D.; Lucht, W.; Kropp, J.P. A Systematic Study of Sustainable Development Goal (SDG). Interact. Earth's Future 2017, 5, 1169-1179. [CrossRef]

3. Kroll, C.; Warchold, A.; Pradhan, P. Sustainable Development Goals (SDGs): Are we successful in turning trade-offs into synergies? Palgrave Commun. 2019, 5, 140. [CrossRef]

4. Downs, A. An Economic Theory of Democracy; Harper and Row: New York, NY, USA, 1957.

5. Key, V.O. The Responsible Electorate; Vintage Books: New York, NY, USA, 1966.

6. Fiorina, M. Retrospective Voting in American National Elections; Yale University Press: New Haven, CT, USA, 1981.

7. Lewis-Beck, M.S.; Stegmaier, M. Economic determinants of electoral outcomes. Annu. Rev. Political Sci. 2000, 3, 183-219. [CrossRef]

8. Hibbs, D.A. Voting and the macro-economy. In The Oxford Handbook of Political Economy; Weingast, B., Whittman, D., Eds.; Oxford University Press: New York, NY, USA, 2006.

9. Lewis-Beck, M.S.; Stegmaier, M. The VP-function revisited: A survey of the literature on vote and popularity functions after over 40 years. Public Choice 2013, 157, (3-4 Special Issue: Essays in Honor of Martin Paldam). 367-385. [CrossRef]

10. Lewis-Beck, M.S.; Stegmaier, M. Chapter 12. Economic Voting. In Volume 1. The Oxford Handbook of Public Choice; Congleton, R.D., Grofman, B., Voigt, S., Eds.; Oxford University Press: New York, NY, USA, 2019.

11. Powell, G.B.; Guy, D.W. A Cross-National Analysis of Economic Voting: Taking Account of the Political Context. Am. J. Political Sci. 1993, 37, 391-414. [CrossRef]

12. Norpoth, H.; Lewis-Beeck, M.S.; Lafay, J.-D. (Eds.) Economics and Politics: The Calculus of Support; University of Michigan Press: Ann Arbor, MI, USA, 1991.

13. Karol, D.; Miguel, E. The electoral cost of war: Iraq casualties and the 2004 US presidential election. J. Politics 2007, 69, 633-648. [CrossRef]

14. Bechtel, M.M.; Hainmueller, J. How lasting is voter gratitude? An analysis of the short-and long-term electoral returns to beneficial policy. Am. J. Political Sci. 2011, 55, 852-868. [CrossRef]

15. Hamann, K.; Johnston, A.; Katsanidou, A.; Kelly, J.; Pollock, P.H. Sharing the Rewards, Dividing the Costs? The Electoral Consequences of Social Pacts and Legislative Reform in Western Europe. West. Eur. Politics 2015, 38, 206-227. [CrossRef]

16. Castater, E.G.; Han, K.J. Trying not to lose: The electoral consequences of unilateral reform efforts and the social pact formation process. Eur. J. Political Res. 2018, 57, 171-193. [CrossRef]

17. Bouvet, F.; King, S. Income inequality and election outcomes in OECD countries: New evidence following the Great Recession of 2008-2009. Elect. Stud. 2016, 41, 70-79. [CrossRef]

18. Ward, G. Happiness and Voting: Evidence from Elections in Europe 1973-2014. Am. J. Political Sci. 2020, 64, 504-518. [CrossRef]

19. Sachs, J.; Schmidt-Traub, G.; Kroll, C.; Lafortune, G.; Fuller, G. Implementing the Goals. SDG Index Report 2018; Sustainable Development Solutions Network: New York, NY, USA, 2018.

20. Cruz, C.; Keefer, P.; Scartascini, C. Database of Political Institutions 2017 (DPI2017). Inter-American Development Bank. Numbers for Development. 2018. Available online: https://mydata.iadb. org/Reform-Modernization-of-the-State/Database-of-Political-Institutions-2017/938i-s2bw (accessed on 15 February 2020).

21. Schmidt-Traub, G.; Kroll, C.; Teksoz, K.; Durand-Delacre, D.; Sachs, J. National baselines for the Sustainable Development Goals assessed in the SDG Index and Dashboards. Nat. Geosci. 2017, 10, 547-555. [CrossRef]

(C) 2020 by the authors. Licensee MDPI, Basel, Switzerland. This article is an open access article distributed under the terms and conditions of the Creative Commons Attribution (CC BY) license (http://creativecommons.org/licenses/by/4.0/). 